\title{
Alpha-Methylacyl Coenzyme A Racemase mRNA Measurement
}

National Cancer Institute

\section{Source}

National Cancer Institute. Alpha-Methylacyl Coenzyme A Racemase mRNA

Measurement. NCI Thesaurus. Code C132365.

The determination of the amount of alpha-methylacyl coenzyme A racemase mRNA in a biological sample. 